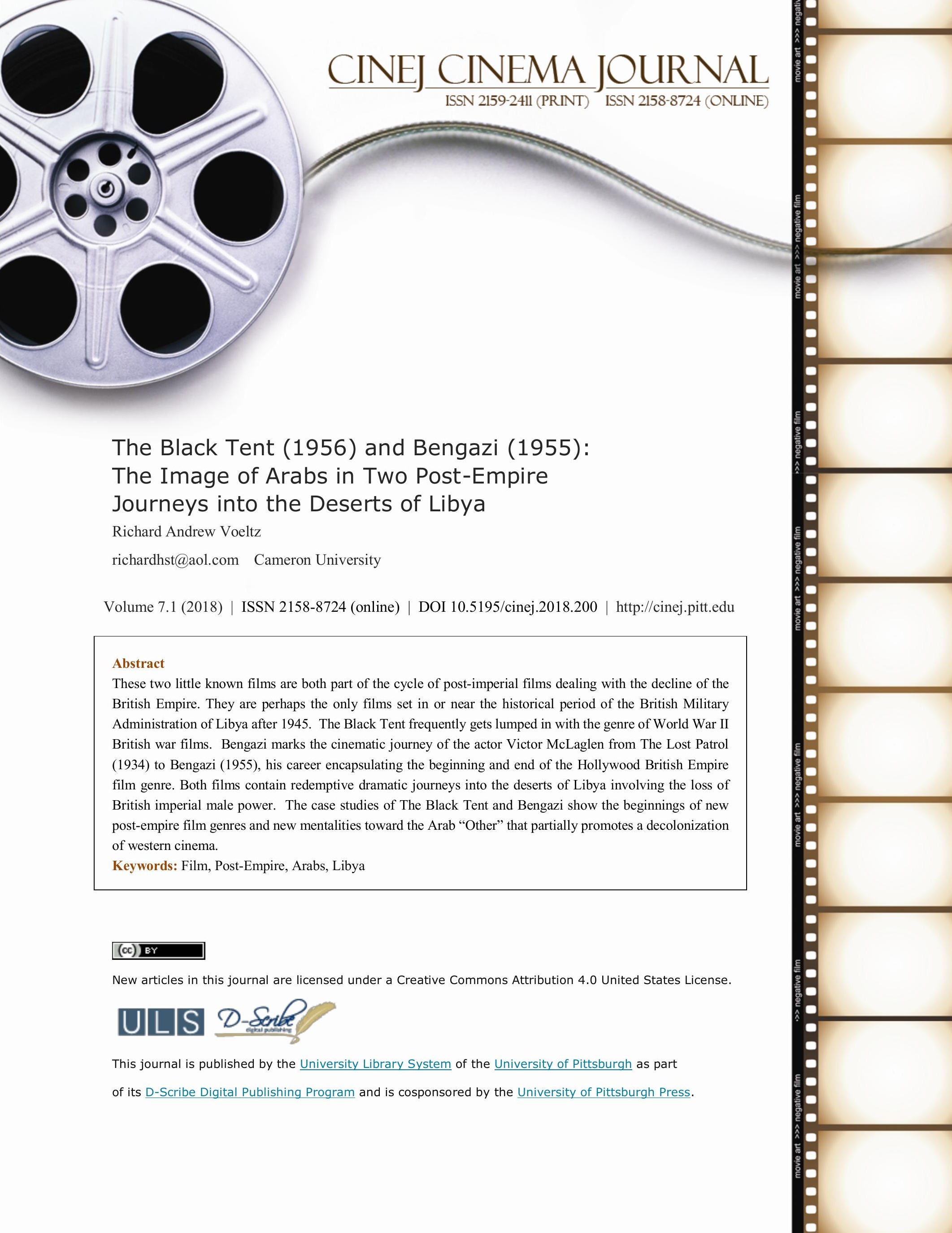




\section{The Black Tent (1956) and Bengazi (1955): The Image of Arabs in Two Post-Empire Journeys into the Deserts of Libya}

\section{Richard Andrew Voeltz}

The Black Tent (1956, British) and Bengazi (1955, American) are perhaps the only feature films set in the last days of the British Military Administration of Libya from 1945 to 1951. They are both part of the cycle of post empire films dealing with decolonization of the British Empire and the representation of Arabs in the post -World War II world by British and American films. Post-empire films can be defined as post-war colonial films that expressed different images and stereotypes than interwar colonial films involving “...the articulation of new political perspectives as well as the defense of old ones" including"...the recognition and validation of the historical experiences of both colonizers and colonized; and the expression of contrition for Western crimes"1 (Cowans, 2015:13). Some of the questions to be asked of such films include, "Do the films seek cultural authenticity? Do they engage in ethnic miscasting? How do the films present the actions and motives of westerners? How do they depict relations between colonizer and colonized....", and how do they address contemporary issues? (Cowans, 2015:13). Despite some validations of the experience of Arabs in both films they still reveal the persistence of American and British colonial mentalities and Arab stereotypes in North Africa in the 1950s and 1960s. Here the difficulty and ambivalence in "De-Orientalizing" the Arab world amid the evolving circumstances of decolonization that demanded new political and cultural perspectives becomes

\footnotetext{
${ }^{1}$ Cowans casts an extremely wide net by using over 100 British, French, and American films, many not immediately recognizable as "Empire" films, to examine popular attitudes toward colonization and race relations. He briefly mentions The Black Tent in terms of miscegenation (p.289), and makes no reference to Bengazi.
} 
apparent. Orientalism as articulated by Edward Said can be briefly defined as a "Western style for dominating, restricting, and having authority over the Orient." (Said quoted in Harlow \& Carter, 1999:49). Arabs and Asians are the primitive "Others". It appears in all manner of cinema from independent art films to Hollywood blockbusters (Bernstein \& Studlar, 1997). The Black Tent flashes back to the North African campaign so it frequently gets lumped in with the British World War II genre film. It also bears the distinction of being the first British film to actually use the landscape locations of Libya, thus presaging the desert vistas of later British and American films, most notably Lawrence of Arabia (1962). Bengazi (The normal English spelling is Benghazi with an h. Hollywood at the time assumed that American audiences did not need any confusion so the $\mathrm{h}$ is omitted.), though a lesser film technically and artistically, marks the cinematic journey of the actor Victor McLaglen from The Lost Patrol (1934) to Bengazi (1955), his career encapsulating the beginning and end of the Hollywood British Empire film genre. The film also offers an interesting contrast in character between a swaggering American (Richard Conti) and a dull, if dogged police inspector and servant of the British Empire played by Richard Carlson, a trope that is found in many British Empire in peril films form the 1950s and 1960s, indicating a loss of masculine control. Both films involve dramatic journeys into the deserts of Libya. In The Black Tent it is a British man looking for his missing in action brother who finds his son instead, the product of a wartime romance with a Bedouin woman. Bengazi features a daughter from Dublin who searches for, and finally finds, her long gone, dissolute, immoral Irish father (McLaglen) who now owns a bar in Benghazi. There is then another journey into the desert in search of Arab gold. Redemptive endings mark the narratives in The Black Tent and Bengazi as well, containing a small degree of contrition as well as what can be interpreted as some recognition of the Arab experience. 
The Desert War between the Germans and the British has always been viewed differently from the other theaters of World War II invoking more nostalgia, adventure, exoticism, romance, and intrigue, from the iconic song Lili Marlene to the larger than life military figures like Rommel and Montgomery. The harshness of the desert environment itself became the common enemy of soldiers on both sides creating a bond between enemies that did not exist on the other fronts of World War II. Aside from Britain's “finest hour” between June 1940 and June 1941 when Britain stood alone against the Nazis, and perhaps the "battle for the Atlantic", few military victories evoke more reverence in Britain than the desert battle of El Alamein. The changing cinematic representation of these events in subsequent years have done so much to shape and encourage the type of remembrance for different generations. British World War II films had to mask a new reality for the post-1945 British Empire. After the war Britain had an exhausted economy and a rapidly disintegrating colonial empire. Britain found its role in the world permanently diminished (Thomas, 2014; Lewis, 1978). Yet, despite this retreat from Empire, the British in 1947 still thought in terms of strengthening their imperial connections with “...Jordan and Libya ...likely to fill the strategic gap left by Palestine (Thomas, 2014). Keeping this in mind, and given the large number of British veterans who had served in the North African campaign, the greenlighting of a film dealing with that campaign, and its aftermath in Libya in the early 1950s, by a major British film studio should come as no surprise.

The Black Tent distributed by the Rank Organization in 1956 and directed by Brian Desmond Hurst, featured the actors Donald Sindon, Anthony Steel, Anna Maria Sandri, Andre Morell and Donald Pleasance. Bryan Forbes and Robin Maugham provided the story and screenplay. Michael Atkinson writing for TCM terms the film an "odd duck" (Atkinson, 2012). That is the case because the film does not fit into one of the three categories that historian Wendy 
Webster identified for British 1950s films about war and empire. The first category, the World War II film, provided "an image of British male Heroism set in the recent past." The Second Category, British films about contemporary colonial wars include such films as Safari (1956) dealing with the Mau Mau revolt in Kenya or The Planter's Wife (1952) which was set during the postwar communist insurgency in Malaya. This category represented a "loss of British male authority and the end of empire." A third strand involved atavistic throw-back imperial films such as Zoltan Korda's Storm Over the Nile (1955), which celebrated the old imperial ethic, attempting to avoid any concerns about the end of empire by being placed in the $19^{\text {th }}$ century (Webster, 2001). Using Webster's schema The Black Tent can be viewed as a hybrid of the first and second categories. Even the film's press book "communicated some mixed messages to exhibitors":

The press book went so far as to state 'But this is not a war film---and it emerges as a major entertainment. This disclaimer concedes that some viewers might... see The Black Tent as a war film, and some of the suggested promotional activities were consistent with those adopted for other 1950s British films associated with the genre. In addition to beauty contests at local dance halls with contestants wearing yashmaks (The double veil or covering for the face worn by Moslem women when in public.), the press book suggested other activities such as foyer displays of the memorabilia from the North African campaign involving ex-members of the tank regiments who served in Tripoli in promotional activities, and inviting high ranking military officers to opening night screenings (Stollery, 2010).

Martin Stollery concludes that, "The alliance between a British officer and Libyan Bedouins avoids complicating the popular memory of the Second World War in a way that involving Indian, African, or West Indian troops, aspiring to postwar independence, might have done" (Stollery, 2010). In fact any explicit references to colonialism are absent with the exception 
of the brief appearance by two British colonial administrators who help Charles Holland search for his missing brother.

The film opens during the grim days of the 1942 British retreat through Libya where we see a young British Army Captain David Holland (Anthony Steel) laying wounded amid wrecked, blazing tanks. He is later posted as missing and presumed dead by the British Army. His country mansion and great estates in England are inherited by his younger brother Col. Sir Charles Holland (Donald Sinden). Evidence emerges that David may still be alive in the form of an official British Army IOU note signed by David found on an Arab who wanted to cash it in Libya. Charles then sets out in search of his older brother years after the war is over, only to uncover the great mystery of David's life, love, and ultimate sacrifice. The bulk of the narrative is then told in flashback from his brother's diary given to him by a Bedouin women who will turn out to be his wife with whom he had a child, Daoud. The badly wounded David is picked up and nursed back to health by a Bedouin tribe of the "black tents" hence the title. He promptly falls in love with the Sheikh Salem's daughter Mubrouka ben Yussef as played by the Italian actress Anna Maria Sandri who knew so little English that her lines had to be completely dubbed by British actress Nanette Newman. When David asks Salem for Mabrouka's hand in marriage, Sheikh Salem (Andre Morell) tells him, "We in our faith recognize the brotherhood of man under the rule of Allah." Mabrouka adds, "With faith you can make anything happen”. The pair soon wed in an elaborately staged Bedouin ceremony. Upon being told that the British are retreating, David seems happy enough to stay with his new Bedouin family. He then learns that the British Army is again on the offensive after Tobruk, so duty trumps love, and he even convinces Sheikh Salem to join him---“"My house is your house - also my sword"-- in waging guerilla war against the Nazis, who for most of the film seem more comedic than sinister, making only brief appearances. David with his new Libyan allies 
attacks a German convoy on a road that looks too modern for World War II. During the battle David dies heroically trying to save Salem. When his brother Charles later arrives in the Bedouin village he sees Daoud who looks suspiciously like his brother, so he realizes he is the true heir to his brother's lavish estate back in England. Raised as a Bedouin the young boy now finds himself having to choose between the life of a desert Bedouin or that of an English lord of the manor. Without hesitation he chooses the desert and his Bedouin way of life. In fact he burns the paper granting him the estate in England. Reviewer James Jennings for Film 4 concluded that you could explain this movie "In a nutshell": "Sit enthralled as a Westerner and an Arab actually decide to make love, not war. (Jennings). More cutting are these two blog posts from current British viewers in the IMDb Reviews and Rating:

It's the kind of nothing movie the BBC used to broadcast on a Sunday afternoon when it knew half the nation would be snoozing in front of the box after a full Sunday roast (Joey the Brit). The only thing that must have stopped this from bombing at the box office was the novelty for the cinema-going public in grey, smog-ridden 1950s Britain of seeing 'real'. 'desert' 'sand in color, something they could have done on the sea front at Clacton or Bournemouth (Christopher Heath from UK). In fact the orientalist spectacle provided by the film did not escape film reviewers in 1956: “...the bright blue skies, yellow sands, palms, and classical ruins of the Vistavision desert scenes, and a Bedouin wedding sequence, give you your money’s worth visually."

Over the years much has been made about The Black Tent being in some ways a precursor to David Lean's great desert epic Lawrence of Arabia (1962). Certainly the cinematography in VistaVision and Technicolor shows the vastness and beauty of the desert. Indeed producer William MacQuitty viewed the film as mainly a "visual drama" which demanded an outstanding cinematographers such as Desmond Dickenson (MacQuitty, 1991:318). And yes there is a camel journey taken across the desert to meet with a tribal chieftain as occurs in David 
Lean's film, although Donald Sinden's character does it in full suit and tie without breaking a sweat. Captain David Holland, blond like Peter O'Toole, finds himself the only Englishman amidst Arabs, and he leads them in a guerilla campaign against the Afrika Korps. In contrast with other World War II desert films such as Tank Force (1958) British and Bedouin fight the Nazis together, reflecting the reality of the British use of indigenous allies during the campaign in Libya. Moreover Bryan Desmond Hurst the director of The Black Tent, although he was proclaimed as "Ireland's most prolific film director of the $20^{\text {th }}$ century" simply lacks the directorial chops of David Lean: "The Irish born Hurst...was an uninspired and rather lifeless filmmaker, despite possessing a rousing biography of war-fighting and bohemian living and rollicking travails with John Ford and John Wayne" (Atkinson, 2007). Lawrence of Arabia certainly had its share of racial profiling with all the principle cast members being either British or American, yet the film at least made an attempt to see the Arab point of view by questioning the assumptions of western imperialism (Chapman \& Cull). While any obvert anti-colonial overtones may be lacking in The Black Tent, Arab characters are also played by British or European actors so they speak perfect English. Donald Pleasance as the Arab sidekick is particularly annoying. Yet it still respects Islam and the Arabs. In fact it makes the Recommend List as complied by Jack G. Shaheen in Reel Bad Arabs: How Hollywood Vilifies A People. But even recommended films can contain howlers and clichéd moments:

An Arab guide (Pleasance) tells Sir Charles, 'I have pictures of girls in Tripoli. Perhaps you find nice girls in Bedouin tents? I will arrange scenes of great delight for you. I am noted for it. Retorts Sir Charles: 'I'm sure you are, but I have more important things to think about'. Quips the guide: "What can be more important than girls' (Shaheen, 2015:116). 
Any concerns about miscegenation raised by the film among a race conscious British public in the 1950s were dissipated by the long standing orientalist romantic and sexual tropes associated with the exotic Orient. Also the fact that the Bedouin woman Mabrouka ben Yussef was played by a European actress further deflected any outrage at black-white relations being portrayed on the screen (Cowans, 2015). The continuing appeal of romantic fantasies about the East or Orient also explain why Daoud's decision to stay there also seemed attractive as witness this review: "Their son, faced with the awful prospect of going back to England with dreary old Donald Sinden, decides to stay in the colorful desert background which is the best thing in the movie." (Johnson, 1956:2). Sir Charles Holland while upright reveals an impotence so great that he cannot even give away his title and estate, thus placing him in the category of Wendy Webster's loss of British male authority. He is a far cry from earlier imperial film figures.

On the surface Bengazi (1955), directed by John Brahm, appears to be a below average action/adventure film set in an exotic, desert location, post-1945 British occupied Libya, a wellestablished Hollywood trope. Near the beginning of the film Inspector Levering intones to Aileen Donovan that, "This is a strange city and strange country. Should you ever need any help I would like to be your friend." It is also firmly in the tradition of previous Hollywood serials and B films in its portrayal of the desert, Arabs, and the Middle East in general. The film frequently played on the under bill in movie theaters just as such Hollywood B serials as Adventures in Iraq (1943) about the mysterious Kingdom of Ghatsi with Arab devil worshipers or A Yank in Libya (1942) where Duncan Renaldo of TV's Cisco Kid fame played heroic Sheikh David (Shaheen, 2015). But Bengazi also puts the final coda on the British imperial Hollywood films of the actor Victor McLaglen. Richard Carlson plays a British intelligence and police officer with the worst 
Hollywood Scottish accent imaginable. ${ }^{2}$ While McLaglen with his parody of an Irish accent is a sleazy bar owner with a daughter (Mala Powers)---just arrived in Bengazi from Scotland---whom he hardly knows. Richard Conte's character Gilmore is a sarcastic, tough guy American expatriate soldier with a New York accent who wants to get his hands on Arab gold buried in the desert. In a sad replay of The Lost Patrol (1934), this unlikely trio of men, along with Powers, end up trapped in a desert mosque surrounded by marauding Arabs. But the world had changed, what had been compelling in the films about the heyday of Empire, now just seems ridiculous, even laughable. The circle had finally closed. From the British Raj to the Hollywood Raj, from The Lost Patrol (1934), The Informer (1935), for which he received a Best Actor Oscar, Wee Willie Winkie (1937) and Gunga Din (1939), and so much more, to finally Bengazi, Victor McLaglen and the British Empire went into permanent decline (Voeltz, 2010).

Unlike The Black Tent which was actually filmed in Libya, the desert landscape came courtesy of location shooting in Yuma, Arizona where an Arab mosque was constructed. The working title of this film was Flight from Bengazi. Joseph Biroc provided the cinematography. (He also did the cinematography for Robert Aldrich's desert drama Flight of the Phoenix (1965). The reviewer for The New York Times termed the film a "...standard little melodrama" and a “...listlessly told offering":

This R.K.O. release holds two very minor assets. The modest desert exteriors are quite cleanly photographed. And for about five minutes, toward the end, Mr. Conte's characterization, that of a hard-bitten expatriate, takes on some semblance of reality. The others are hopelessly

\footnotetext{
2 The Hollywood career of Richard Carlson really arrived in 1950 when he co-starred with Deborah Kerr and Stuart Granger in the highly popular imperial jungle adventure King Solomon's Mines (1950) shot on location in Africa. Here his fake English accent is no better than his attempt to fain a Scottish accent in Bengazi. "Richard Carlson".
} 
hogtied, however. Obviously Director John Brahm and his two scenarists, Endre Bohem and Louis Vittes, have taken it easy. Perhaps it's just as well. The pretty Miss Powers does seem natural enough as a guileless Irish colleen who attracts both Mr. Conte and Mr. Carlson, a British inspector with an iron Scottish burr. Richard Erdman looks in briefly (and convincingly) as an ex-convict. The always welcome Hillary Brooke, as a tarnished Swede, is all but whisked out the window. And Victor McLaglen, whose cloying Irish brogue seems heavier than the Blarney Stone itself, makes "The Informer" seem mighty long ago and far away (H:H.T, 1956).

John Brahm had established a reputation in Hollywood as a director who could remake movies by giving them new titles and/or sprucing up old formulas. He did a 1938 version of D.W. Griffith's Broken Blossoms, a rip off of The Wolf Man (1942) titled The Undying Monster (1942), and a 1944 remake of Alfred Hitchcock's The Lodger. During the 1950s and 1960s he directed numerous episodes of Alfred Hitchcock Presents and The Twilight Zone before returning to the big screen with Bengazi. His final feature length film was Hot Rods to Hell (1967), a competent, taut action film that features Dana Andrews and his family being tormented by hot rod juvenile delinquents instead of marauding Bedouins (Smith, 1968).

In Bengazi Brahm and the screenwriters recycle narrative points and scenes from such films as Casablanca (1942), To Have and Have Not (1944), Treasure of the Sierra Madre (1948), Desert Nights (1929), for which screenwriter Endre Bohem shares a writing credit, and particularly John Ford's classic The Lost Patrol (1934). From Casablanca comes Donovan's Bar Bengazi, Libya instead of Casablanca, Morocco, owned by Irishman Robert Emmett Donovan, estranged from his wife and daughter back in Dublin for some fifteen years. His American partner is Johnny Gilmore (Richard Conte), a stand-in for Bogart. Mala Powers as Donovan's daughter Aileen even resembles Ingrid Bergman. Donovan and Gilmore are involved in all sorts of nefarious activities such as running guns to the Arabs, reminiscent of Humphrey Bogart again in To Have and Have 
Not. The two are always under the watchful eye of British Inspector Levering (Richard Carlson) similar to the character Captain Louis Renault in Casablanca. As in Desert Nights and The Treasure of the Sierra Madre it is greed for diamonds and gold that drives the respective trios of protagonists in those films forward into the wilderness until a redemptive end when the good guys lose their treasure to the indigenous people. Interesting to note that Henry Hathaway's Legend of the Lost (1957), like The Black Tent filmed on location in Libya, and starring John Wayne, Sophia Loren, and Rossano Brazzi, features yet another trio in search of lost treasure in the deserts of Libya. Wayne played Joe January, a hard drinking, hard living American ex-patriot guide who dresses like his character in the later western Rio Bravo (1959).

But Bengazi seems most derivative of John Ford's classic empire film The Lost Patrol (1934) starring Victor McLaglen, Boris Karloff, and Reginald Denny, and marked by the conspicuous absence of any women in the cast. A British silent version of The Lost Patrol (1929) starring Victor McLaglen's brother Cyril was actually filmed in the Sahara. In the 1934 remake, enduring the hardships of filming in the Yuma Desert, McLaglen (only The Sergeant in the cast credits) played the leader of a British patrol in Mesopotamia during World War I that is being picked off one by one by an unseen Arab enemy. In the opinion of Jeffrey Richards "it emerges as a respectful and expertly handled tribute to The British Soldier.” (Richards, 1973: 173-174). In his review, Gregory William Mark writes, "So powerfully does Ford build his film that many audiences cheered in vicarious and violent release as McLaglen viciously and manically slaughtered the Arabs who finally revealed themselves" (Shaheen, 2015:335). The photogenic rolling sand dunes in the film do not match the dry terrain in Mesopotamia (Iraq) and it is never revealed why and for whom the Arab enemy is fighting. At least in Bengazi it was their gold after all. The heat allowed John Ford to have McLaglen go shirtless to reveal his burly chest, as Brahm 
does for Richard Conte in several scenes. Both films feature sieges taking place in an oasis next to an abandoned mosque. The Arabs steal the horses of the British soldiers in The Lost Patrol, while in Bengazi they take their truck thus marooning the group. Both movies have scenes of a man mysteriously being stabbed in the back by an Arab who then disappear into the desert. In Bengazi the victim is Selby (Richard Erdman) an ex-British soldier who spent two years in prison for almost killing a Bedouin and who knows precisely where the gold is buried. Both films show deranged men wandering off into the dunes to be killed. In The Lost Patrol one of the three last survivors Sanders (Boris Karloff), a religious fanatic quoting from the Bible and carrying a cross gets killed, while Donavan recklessly exposes himself to order to help his daughter. Both films feature an airplane landing near the oasis that seems to offer an escape. The plane in Bengazi carries Aileen and Levering. But both planes are destroyed while on the ground and the pilots killed. In The Lost Patrol McLaglen retrieves a machine gun from the burning plane; while Gilmore extracts a machine gun from the military truck that he had stolen from the British Army before the Arab made off with it at the desert mosque. Fernando F. Croce writes that "McLaglen's climatic machine ejaculations aren't an officer's fierce triumph, but a dead man's scabrous spasms" (Croce, 1994:1). Gilmore also has a machine gun fetish, calling the gun "Baby", and saying "speak to me, Baby", while he keeps the Arab at bay with it, "They don't like Baby talk." He eventually runs out of ammunition. At the end of The Lost Patrol the only one of the twelve to be rescued by British troops is the sergeant (McLaglen), whose emotions ran from the utter futility of this war to the primitive joy of killing Arabs.

In the Bengazi version of the Arab siege, Aileen, Gilmore, and Levering also seem doomed at the end. Aileen and Gilmore now express their love for each other. The next morning Gilmore digs a grave for one of Levering's police colleagues Peters hitting a metal box containing the Bedouin gold. While ignoring the pleas of Aileen and Levering he carries it outside. The Bedouins 
wound Gilmore but he keeps moving toward them, finally offering them the gold in exchange for the lives of Aileen and Leverings. At the mosque Levering understands that Gilmore is trying to save them as Aileen weeps for Gilmore. She is then overcome with joy when the Bedouins suddenly appear out of the dunes with Gilmore in tow, along with the stolen truck. The Bedouins withdraw leaving the three survivors in peace. After Levering tells Aileen that she and Gilmore are free to go, Aileen runs to embrace Gilmore. Thus Johnny Gilmore redeems himself at the final fadeout for his greed and prior misspent life with an act of heroism and self-sacrifice.

In Bengazi, Arabs appear threatening except at the very end, and are referred to as "tribes" or "natives", with assertive Libyan youths hassling Aileen Donovan for money before being run off by Gilmore. But mostly they are invisible, even when threatening the protagonists. The only time recognizable Libyans appear in the film they are quarrelling in Donovan's Bar with a woman singing in Arabic. The only Libyan with a speaking part in the film, Basim, who helps Gilmore in the heist of the British Army lorry at the at the start of the film, is played by American actor Jay Novello, who specialized in ethnic roles, especially Italians and Mexicans or anyone else of a darker complexion. Ironically, a British officer even goes undercover as an Arab at one point in the film. While The Black Tent features more Libyans as extras, having a Shakespearean actor Andre Morrel play the Sheikh or Donald Pleasance assume the role of a smirking fez wearing, $\tan$ dyed Arab servant acting in "yellow face" does not much enhance Arab authenticity either.

There is also an interesting contrast between the American Johnny Gilmore and the British officer Levering. While wounded in the leg during the siege in the desert mosque, Levering speaks wistfully about his home in Scotland --"I'm thinking of the wee village in Scotland where I was born"-- wanting to whisk Aileen away with him to that place where there flows "a beautiful little stream, nothing like your great Liffey, but fine nonetheless". Of course Gilmore not only gets the 
girl but becomes the hero proving the fundamental ineptness of Levering who comes across as sincere but ineffective. This depiction places the film in Wendy Webster's second category of post-war films that define "the loss of British male authority and the end of empire." (Webster, 2005:140-142). Gilmore represents the confident "can do" attitude of America as opposed to the tight laced, rule loving Levering. Gilmore also gets all the good lines. When he stares hard at Aileen for the first time, she quips “Haven't you seen a woman before?". He responds, "I've had steak before, but that does not mean I don't want it again." Gilmore also explains his existential existence in Libya: "'You know the army grabbed me when I was a kid. Out of the army all that was left was a big open space in the middle of the road." He vows not to go back to the small town in upstate New York where the only job he could get was pumping gas and washing windshields, "I could have had two pumps by now. No thank you." Set in British controlled Libya Bengazi is among a number of empire in danger films from the 1950s and early 1960s where British colonial officials had to walk a thin line between portraying duty, courage, and dedication to empire, with a British sense of fairness, even in the face of what was perceived as primitive barbarism in the revolts against British rule. The feature films and documentaries of this genre had Americans play key roles as characters, actors, presenters, or producers. Examples would include Safari (1956) with Victor Mature, Something of Value (1957) with Rock Hudson, The Seventh Dawn (1964) with William Holden, and the American made documentary Mau Mau (1955) narrated by American newsman Chet Huntley. American actresses also had significant leads in such films as The Planter's Wife (1952) with Claudette Colbert and The High Bright Sun (1964) starring Susan Strasberg. Such prominence afforded Americans indicated the tangled, contradictory nature of the "special relationship" between Britain and America in spite of shared Anglo-American values that made the cinema of empire clearly a "mid-Atlantic" phenomenon. These films in their time tried to capture American, Cold War, and world sympathy, by emphasizing the idea of the British 
Empire being in mortal danger. In a very real sense these were the last films of a parochial British Empire before "empire" went global at least cinematically in the persona of James Bond in Dr. No $(1962)^{3}$. Bond manages to safe himself and the world by a combination of imperial pluck and snobbery besting not only the bad guys but his American CIA counterparts as well. This was one of the ways which Britons came to terms with the fact that their actual role in the world had ebbed away. The Americans of course would assume the mantle of authority from Britain in North Africa and the Middle East as well as the rest of the world while Britain was left searching for a new role.

Both Bengazi and The Black Tent came out during a specific time of uncertainty about the role of an emerging Arab Nationalism with Nasser in Egypt and the future of British power after the Suez Crisis of 1956. Michael Atkinson termed The Black Tent (and by inference Bengazi as well) "...a politically loaded film, as are so many that dare to probe the legacy of the colonial era in the postwar culture....Hurst's film tries to find a balance between stiff-lip British supremacy and the self-possessed gravitas of 'native' peoples" (Atkinson, 2012:1). The Black Tent does attempt to treat Arab culture and Islam with at least a measure of respect and shows how the indigenous population of Libya had to deal with both the British and the Germans in their country during World War II. The Sheikh's espousal of Islam as an open and accepting religion certainly is significant. Daoud's rejection of his inheritance in Britain validates the importance of his culture, as does Charles Holland's combination of impotence and contrition in offering up the Inheritance to Daoud in the first place. Inspector Levering in Bengazi, while upholding the British Empire, does make a modest attempt to understand the Bedouins. When asked why the Bedouins don't use

\footnotetext{
${ }^{3}$ For further discussion see Richard A. Voeltz, "The Cinema of the Empire in Peril: From Malaya to Mau Mau", paper presented at the annual meeting of the Western Conference on British Studies held at Kansas City, Missouri, October 3-5. 2013.
} 
banks to hold their treasure, he paternalistically responds with, "We have been trying to get them to do that." At the end of the movie the Bedouins are shown in a very sympathetic light as they let the surviving trio go free, even after they tried to steal their gold, because of what can be viewed as an act of contrition on the part of Gilmore. Contrast this ending with that of The Lost Patrol where the unseen Arabs show no mercy. The paternalistic British colonialism of Levering gets contrasted with the presumed American benefice and ecumenicalism as represented by Gilmore. The film also makes clear that the disreputable, sleazy character Shelby late of the British $8^{\text {th }}$ Army did jail time for assaulting a Bedouin, making his death at their hands as something that seems justified. However, the likelihood of American or British soldiers in North Africa being punished for assaulting or even killing Arabs in North Africa during World War II would have been highly unlikely. American soldiers were known to shoot Arabs for sport (Atkinson, 2007:169). And the fact that Shelby had killed a British intelligence officer who was undercover as an Arab certainly factored more in his deserved death than assaulting real Arabs.

Both cinematic conclusions of The Black Tent and Bengazi offer a degree of contrition and affirmation of Arab culture by Gilmore and Charles Sheldon, not to mention David's marriage to a Bedouin woman that produced an heir to his estate, thus affirming the positive values of Arab and Islamic culture. The stereotypical treatment and varying degrees of denigration of Arab culture found in both films, along with the redemptive and contrite endings create a clear ambivalence about Arab culture. The ambivalence found in these two films supports the overall argument by Joe Cowan in Empire Films and the Crisis of Colonialism that "Postwar films on colonialism turned increasingly ambivalent, even anti-colonialist, creating new functions for the genre." In short, "Empire films...became more politically complex after World War II. Who were the 'good guys'? Who were the 'bad guys"'? (Cowans, 2015:13). In their ambivalence about colonialism these two films may have moved beyond the cartoonish depictions of Arabs found in $A$ Yank in 
Libya, but it would some time before Arab culture and characters would get an honest profile in movies. The "De-Orientalization" of Arab culture and Islam will take a very long time and still remains a work in progress. Even in films such as Lawrence of Arabia (1962), The Sheltering Sky (1990), The English Patient (1996), and many more, including the recent Thirteen Hours: The Secret Soldiers of Benghazi (2016) about a siege in a very different Benghazi, shades of European colonialism and racism still persist (Shaheen, 2015). Both The Black Tent and Bengazi remain artifacts of a different consciousness, one that was caught between the demanding forces of decolonization and a past that was rooted in empire, war, imperialism, and racism. Bengazi also has the distinction of being a film that encapsulated both the alpha and omega of the older Hollywood British Empire cycle as well as Victor McLagen's acting career. Both films but Bengazi in particular reveals an end of empire loss of British male power and effectiveness. Despite decolonization and its aftermath Hollywood still puts forth old racial and cultural stereotypes. The case studies of The Black Tent and Bengazi show the beginnings of new post-empire film genres and new mentalities toward the Arab "other". However, there still exists no equitable and reciprocal exchange of cultural values and images between the West and the Arab world that would promote a true decolonization of knowledge and western cinema.

\section{BIBLIOGRAPHY}

Atkinson, R. (2007) The War in North Africa, vol. One of the Liberation Trilogy, New York: Holt

Atkinson, M. (2012) “The Black Tent”, TCM, http://www.tcm/thjimonth/article/411149\%7C38767/The-Black-Tent-html.

Bengazi (1955), "Notes", TCM, http://www.tcm.com/tcmdb/title/2984/Bengazi/notes.html. Bengazi (1955), "Filming Locations", IMDb, http://www.imdb.com/title/tt004872/locations. 
Brahm, J. (1970) The American Cinema: Directors and Directions, 1929-1968, London:

Routledge.

J. Chapman \& N. Cull, eds. (2009) Projecting Empire: Imperialism and Popular Culture, London: I.B. Tauris.

Cowans, J. (2015) Empire Films and the Crisis of Colonialism 146-1959, Baltimore: Johns Hopkins University Press.

Croce, F., (1994) “The Lost Patrol (John Ford/US, 1934), http://www.cinepassion.org/reviews/I/LostPatrol.html.

“Garden-of-Allah", The Daily Worker, March 17, 1956 as quoted in Stollery, p.2. Considerable action takes place among the Roman ruins of Sabratha. "The Black Tent (1856) Goofs", p. 2 . IMDb, www.omdb.com/title/tt00490141/goofs. Accessed 10/15/2016.

Harlow, B. \& Carter, M. eds. (1999), Imperialism and Orientalism, A Documentary Sourcebook, London, Blackwell.

H.H.T, (1956) "Bengazi — at the Palace is Standard Fare", New York Times, http://www.nytimes.com/movie/review/?res=9D02EE53BBC405DFB6678E649EDE\&pagewant ed=print.

Jennings, J. (1956) “The Black Tent---Film 4”, http://www.colonialfilm.org.uk/node/6733.

Johnson, F. (1956) “Review of The Black Tent”,s Reynolds News, March 18, 1956.

Joey the Brit and Heath, C. (2010) “The Black Tent Reviews and Ratings", IMdB, http://www.imdb.com/title/tt0049141.reviews.

Lewis, W. R. (1978) Imperialism at Bay, The United States and the Decolonization of the British Empire, 1941-1945. New York and Oxford: Oxford University Press.

MacQuitty, William. (1991), A Life to Remember: Quartet, 1991.

Matthew, B and Gaylen, S. eds. (1997), Visons of the East: Orientalism in Film, New

Brunswick: Rutgers University Press.

Murphy, R. (2000) British Cinema and the Second World War. New York and London:

Continuum.

Richards, Jeffrey, (1973), Visions of Yesterday, London: Routledge.

Shaheen, Jack (2015), Reel Bad Arabs: How Hollywood Vilifies A People, Northhampton, MA: Olive Branch Press. 
Smith, R. H. (1968) Bengazi (1955-Articles, TCM,

http://www.tcm.com/cmdb/title/2984/Bengazi/articles.html. P. 1. Accessed 11/24/2015. "John

Brahm", The American Cinema: Directors and Directions, 1929-1968. New York: Da Capo

Press.

Stewart, I. \& Carruthers, S. eds. (1996) War, Culture and the Media: Representations of the Military in $20^{\text {th }}$ Century Britain. Madison and Teaneck: Fairleigh Dickenson University Press, esp. pp. 75-90.

Stollery,M. (2010) “The Black Tent”, p.1, http://www.colonialfilm.org.uk/node/6733.

Smith, Richard Harland, (1955), "Bengazi (1955 Articles)”, TCM,

http://www.tcm.com/cmdb/title/2984/Bengazi/articles.html.

Thomas, M. (2014), Fight or Flight: Britain, France, and their Roads from Empire, New York: Oxford University Press.

Voeltz, R. A. (2010) "Victor McLaglen, the British Empire, and the Hollywood Raj: Myth, Film, and Reality, Journal of Historical Biography, 8, www.ufv.ca/jhb.

Wendy Webster,( 2001) “There'll Always Be An England: Representations of Colonial Wars and Immigration, 1948-1968," The Journal of British Studies, 40, 4.

Wendy Webster, (2005) Englishness and Empire 1939-1965, Oxford University Press, Oxford and New York: 2005. 